\title{
The Loss and Backtracking of Sense of Place - Soundscapes in
}

\section{The Town and the City}

\author{
Shuyao Huang", Joan Qionglin Tan \\ College of Foreign Languages, Hunan University, Changsha, China
}

*Corresponding Author: Shuyao Huang, College of Foreign Languages, Hunan University, Changsha, China

\begin{abstract}
The Town and the City is the first novel of Jack Kerouac, a representative of the "Beat Generation" in America. Different from other works with "free-flowing" prose-like artistic features, this semiautobiographical novel is more traditional. It narrates the family saga of the Martins, who move from the small town, Galloway, to the big city, New York. Based on the key words of "soundscape and sense of place", this paper draws on the theories of soundscape, human geography, sociology and memory psychology to explore how Kerouac presents characters'various emotional experience in the processes of growth, leaving hometown and returning hometown by the description of soundscapes in different time and spaces. Meanwhile, it aims to elucidate the connection between soundscapes and the identity of characters, the construction and backtracking of sense of place in this novel.
\end{abstract}

Keywords: Jack Kerouac; The Town and the City; soundscape; sense of place

\section{INTRODUCTION}

The term "soundscape", first proposed by the Finnish geologist Johannes G. Granoe (1882-1956) in 1929 , is a compound word consisting of "sound" and "scape". "Soundscapes are the totality of all sounds within a location with an emphasis in the relationship between individual's or society's perception of, understanding of and interaction with the sonic environment" (Farina 3). The Canadian composer Raymond Murray Schafer (1933- ) took the lead in the study of soundscape from 1960s to 1970s. In 1977, he published the book Our Sonic Environment and the Soundscape: the Tuning of the World, which describes the evolution of soundscape in the development of human civilization, and discusses how to identify the quality of soundscape in the surrounding environment, or to use soundscape to create a healthy acoustic environment. As a new branch of ecology, soundscape arouses people's attention to the acoustic environment, and is widely applied to urban planning, landscape design, noise pollution prevention and other related fields. At the same time, soundscape emphasizes the sense of auditory perception and human's understanding of sound, which injects aesthetic significance to it. Schafer indicated that "certain sounds possess strong symbolic character" and "some of the most ancient may act to invoke archetypal symbols" (169). For example, of all sounds, water, with the forms of rain, stream, fountain and river, has the most splendid symbolism in literature, myth and art, which speaks of "cleansing, of purification, of refreshment and renewal" (Schafer 169). Soundscape has rich cultural connotations. All kinds of sounds produced and spread in regional spaces are important references for people to understand experience and obtain basic geographic information in their daily lives, and is also the basis for people to construct their spatial perception (Liu 1454). Meanwhile, soundscape's abundant socio cultural implications embodied in some special soundscapes, such as dialects and folk songs, are also important carriers of sense of place, which is of great significance to the formation of local identity.

The Town and the City (1950) is remarked by Kerouac as the prelude to his famous work, On the Road (1957). As the young Martins grow up in the small town of Galloway, they gradually build up their inner sense of place and identity. After the loss of their hometown at physical and spiritual levels, the family members come to New York, experiencing the fierce collision between traditional and modern values, and the confusion and choice in the war. In the end of the story, by returning to the hometown, they regain a sense of place, rebuild their local identity, and then reorient their way of life. 
This paper takes the novel, the Town and the City, as an example to analyze the inner connection between soundscape and local identity, as well as the construction and backtracking of sense of place. The author thinks that, Kerouac conveyed his own thoughts on the relationship between "sense of place" and "on the road" through this work: whether one is at the hometown or not, as long as the soul achieves a sense of belonging, then one is able to regain the sense of place and return to his spiritual homeland. In this process, a specific soundscape is a physical stimulus and catalyst to evoke the sense of place and to remold local identity.

\section{The TOWn: A CARrier of SENSE OF PlaCe ANd LOCAL IDENTITY}

The Town and the City is Kerouac's semi-autobiographical novel, which imitates the style of his idol, Thomas Clayton Wolfe (1900-1938). He took his hometown Lowell in Massachusetts as the prototype of fictional "Galloway", where the Martin family resides for several decades. This place can be considered as Kerouac's psychological reconstruction of his hometown, an "idealized" hometown based on his specific mental state and feelings of the past (He 155). The story begins with the natural and humanistic landscape of Galloway: The town of Galloway winds along the river; it is a "milltown in the middle of fields and forests" (Kerouac 3). Tombstones on hillsides record the dead ancestor's name; suburban streets are quiet and depressed at night, while in the morning, squares are busy and orderly. In this landscape, numerous sounds interweave into a soundscape, like a "sound curtain on the background of a story" (Fu 60), laying the basic acoustic atmosphere of the small town. Based on the definition of the three overlapped sonic sources of soundscape by Farina, the rush of the Merrimack River and the sound of the wind's blowing to leaves all belong to geophonies, which set the tone for Galloway's entire soundscape and contour the whole picture of sound. The barking of dogs from time to time at night, the coughing of people in the morning, and the bustling sound of townspeople are the representatives of biophonies, which are relatively short and sharp, easy to attract attention. The machine buzzing in the textile factory and the car whistle in the square belong to anthrophonies, which are the symbols of industrial development and the main source of noise. These three kinds of soundscape constitute the basic characteristics of the acoustic environment in the town of Galloway. As a direct and effective supplement to the visual experience, soundscape infuses every aspect of the life of the Martin family. The auditory experience has entrenched a deeper understanding of the place in the mind of young members as they grow up, thus "a map is inscribed in the mind" (Snyder 28), by which they are able to re-visualize the place both with its sceneries and sounds. The famous humanistic geographer Yi-Fu Tuan once discussed the relationship between human and their perception of the place, that is, we need enough time to make an abstract and practical understanding of the atmosphere of a place. The sensory organs, such as sight, touch, hearing, taste and smell, enable us to have their strong feeling for space, size, distance, textures, and "provide the intricately ordered and emotion-charged world in which we live" (11-15). "Yet the child is father to the man, and the adult's perceptual categories are from time to time infused with emotions that surge out of early experiences"(20). The beginning part of the novel narrates children's "riverside broodings": "The little children of Galloway sit on the banks of the Merrimac and consider these facts and mysteries. In the wild echoing misty March night, little Micky Martin kneels at his bedroom window and listens to the river's rush, the distant barking of dogs, the soughing thunder of the falls, and he ponders the wellsprings and sources if his own mysterious life" (3). In the process of growth, children measure their place with their keen senses, and establish emotional connection with the place because of their related individual experience. This emotional connection is called "sense of place", in which the auditory experience plays an indispensable part.

In addition, the function of sound is also reflected in the emotional ties of the Martin family and Galloway's geographical ties. There are eleven members in the Martin family. The father, George Martin, comes to Galloway when he is young and then he enters the printing industry with success. His wife Marguerite gives birth to three daughters and six sons. Before 1938, the year when the eldest son Joe Martin leaves home, the whole family members live in an old gray house on old Galloway Road. In this small space unit, the communication and collision between the individual voices of the family members make up a rich soundscape: the emotional appeal between Marguerite and her daughter Rose; the heated debate between Peter and his brother Francis over the question of "philosophy of man"; the whole family's watching Peter's first football match and the celebration of his victory on Thanksgiving Day. Although there is a significant difference in the individuals' voices in the family, "that is hidden by allowing one voice - traditionally the father's voice - to dominate" 
(Tuan 309). With a steady income and amiable personality, the father, George Martin, is the patriarch of the family and is worshiped and admired by his wife and children. He leads the voice power in the family. Therefore, in a certain period of time, the different individual voices in the family are restrained; the members coexist harmoniously and the emotional connection deepens. At the same time, as a kind of extension and supplement of family relationship, communication in community is also the key to geographical emotional bond. Yi-Fu Tuan called "the small community that embrace certain mannerisms of speech and jargon to exclude the uninitiated and heighten the contrast between "us" and "them" as "community with specialized language" (315); it emphasizes the difference between members and non-members, and the members are closely connected by a common gift or interest. In the space of Galloway, small groups, such as Peter Martin's baseball team members, the duo of Peter and Alexander, and Marguerite's religious worship group, are typical examples. Their communication involves professional competitions, poetry and music, religious life and so on. This relatively equal communication promotes the resonance of spiritual and emotional voices. Meanwhile, the dialect that often appears in the novel is one of Galloway's signal sounds, which is beneficial for individuals to identify each other and increase intimacy in communication. The communication of sounds promotes the emotional ties between individuals and their families, and the geographical ties between individuals and their community members, which further deepens the sense of place.

\section{The City: The Loss of Sense of Place}

Yi-Fu Tuan once discussed the spiritual connotation of "home" and "place" with the example of the protohuman's cave: "[t]he cave as enclosed space serves a similar purpose: it not only keeps nature out, it also contains the psychic energy of its dwellers, intensifying their awareness of one another. And so throughout the ages, wherever human beings build an enclosed space, they also create an intimate human cocoon" (Tuan 48). In the spring of 1941, when George Martin goes bankrupt, the family is forced to move out of the old gray house on old Galloway Road and move twice to the underground apartment on Brooklyn Street in New York in the following two years. During that time, the family members leave home for various reasons. From Galloway to the metropolitan New York, the change in spatial soundscape brings a great deal of strangeness and discomfort: "In the late afternoon of Brooklyn, there hummed and roared the multiple sounds of a great city" (Kerouac 344); "the bus crossed more bridges and suddenly the apartment house loomed everywhere immediately above, and the streets were suddenly zooming by in explosions of light and traffic and thronging crowds" (Kerouac 356). "...they had a vision of hundreds of thousands, perhaps a million street corners in all of New York, perfectly square and measured, and each one, as well as the intervening space between corners, thronged and trafficked and peopled and furious" (Kerouac 358). The city soundscape which is filled with mechanical noise suppresses all kinds of natural sounds, and the lowfidelity sound effect makes people uncomfortable. At the same time, the outbreak of war puts people under the hegemony of sound, making sound a tool of oppression (Fu 63). As Zhou Zhiqiang said: "[c]ollective chorus and loudspeakers not only represent an undifferentiated group, but also show the demands of the ruling class on the collectivism of the state authority... Sound is always more easily attached to power and becomes an effective means of social control" (10). Upon hearing the daily news of the war on the radio, the youth of the Martin family are eager to enlist. Soon, the war begins everywhere. "It was a railroad landing and the crowds of khaki-clad soldiers searching eagerly, or waiting casually, or singing and shouting, and the sad blur of their faces as the train departed, and the vast infinite rolling land again, the oncoming of nighttime again, the clacking wheels", Joe achieves his dream by joining the air force and becoming a sergeant. With an adoration for his brother's "manly and pitiful" decision, Peter becomes a sailor on a merchant ship named Westminster; one night, he witnesses that the Latham, the sister ship of the Westminster is bombed, and "a vast sustained roar, far off, and wails and cries directly overhead sent him topside with his lifebelt" (Kerouac 289; 296; 306). Francis cannot bear the censure of the naval officer and has to escape from the camp on a pretense of madness. George Martin has experienced the World War I and he regards the war as "the same stupid and violently unreality" (Kerouac 273). Fearing that the horrible scene of 1917 will be repeated again, he grieves his sons' choice to join the army but is unable to change their mind and let them come back. His voice in the family begins to wane as other members move away. Meanwhile, his business goes bankrupt and his body goes from bad to worse, which further weaken his voice dominance. From the New Year's Eve of 1941 to the end of the war in 1945, the members of the Martin family scatter in New York, Seattle, Detroit and other places and they never reunite for the rest years. In addition, the old friends in Galloway's geographical circle, as the extended form of family ties, are also separated 
from each other during the war. People gradually lose the physical and the spiritual shield of "the enclosed circle of human cocoon"(Tuan 48). Consequently, the verbal communication between each other wanes and the relationship among family members and community members is gradually estranged.

The alienation between people is more obvious in New York, a social space which is full of strangeness. The German sociologist Georg Simmeli (1858-1918) first introduced the concept of "social atomization". It is said that "atom is the smallest unit of material that can exist independently and is weakly related to each other" (Niu 117). The philosopher Hammah Arendt (1906-1975) further deepened the concept and proposed that people in modern society are atomized individuals who are lonely, absorbed in the material enjoyment, and completely "private". There is no strong connection between these individuals" (Niu 117). Peter hears Levinsky talking about the virus X: "You will eventually (see). Everybody is going to fall apart, disintegrate, all character-structures based on tradition and uprightness and so-called morality will slowly rot away... Listen! You know about molecules, they're made up according to a number of atoms arranged just so around a proton or something. Well, the 'jus-so' is falling apart. The molecule will suddenly collapse, leaving just atoms, smashed atoms of people, nothing at all" (Kerouac 371). The moral constraints of the society are disappearing, and the interpersonal ties are gradually lost. Denison turns a blinded eye to Peter's visit, and cooks morphine while holding the baby; people react indifferently to Waldo's suicide.... The failure of communication between people, the loneliness and fear of the individuals make them "roar" madly from the heart. A demented man in a dirty tattered robe makes speeches quoted from Hamlet: "You there! Pick up your pen, son, and write against the evil in this world. My little son and brother, if thou didst ever hold me in thine heart, absent thee from felicity awhile, and in this harsh world draw thy breath in pain, to tell my story" (Kerouac 351)! The sudden garish sight of some incredible homosexual flouncing by with an effeminate shriek of general greeting to everyone, anyone: 'I'm just so knocked out and you all know it, you mad things"' (Kerouac 361). In this process, Peter Martin's spiritual space also changes: at first, he yearns for big cities, and then, in the face of the cruelty of war and the impact on his traditional ideas, he is at loss, confused, and lonely. He is desperate to go back to Galloway. He says, "I am driven and weary" (Kerouac 280). And "it was as though something had broken inside him, all fallen and ruined...in the strange unthinking world, all awful and raw and grieved" (Kerouac 439). When people find that freedom is under great threat, they become hostile to the city, and alienation occurs; this is specifically reflected in reducing the frequency of responding to others and responding to stimuli. Fei Xiaotong (1910-2005) called this behavior as self-preservation, or self-retirement (Sun 140).

\section{Returning Hometown: The Backtracking of Memory and the Recovery Of SenSE OF PlaCe}

He Ping believed that both the Eastern and Western motifs of "returning homeland" indicate a strong sense of seeking spiritual homeland, for they are all in a transitionary era of upheaval where man is out of touch with society and need to feel belongingness. (74). Misfortunes and the cruelty of war leave the members of the Martin family homeless, both physically and spiritually. After the war, the young members return to New York to visit George Martin, who is suffered from cancer. As a result, the members begin to reunite to enhance emotional exchange in the form of communication. When Joe comes back, George Martin "cried, and laughed and joked, and cried, and hugged his son, and talked and cried again" (Kerouac 445). Joe shouts excitedly every time he hears from his father about the rest members of the family. The reconnection of the family members makes their warm memories of Galloway back together: Elizabeth feels that "the dark secret gladness brooded back there in Galloway, and waited for her, and mourned like the wind at night in October, and something knocked against the house making summons and grieving, she was not there" (Kerouac 458). Peter's communication with his father is no longer a quarrel; after a gentle long conversation with his father, he even deepens his understanding of life, of the old gray house where he grows up. He realizes that "all the poor fumbling uncertain incompletions of human endeavor went on forever and were forever far from perfect, full of failure and fears of failure, yet, in the way of things, somehow noble, complete, and shining in the end" (Kerouac 472). "This he could sense even from the old house they lived in, with its solidly built walls and floors that held together like rock: some man, possibly an angry pessimistic man, had built the house long ago, but the house stood, and his anger and pessimism and irritable laborious sweats were forgotten; the house stood, and other men lived in it and were 
sheltered well in it" (Kerouac 472). According to the definition of memory psychology, sensory memory, such as iconic memory and echoic memory, is stored instantly after the stimuli have ceased. Part of the sensory memory is "stranded", and then encoded and stored by the brain to become a longterm memory (Yang 25). The backtracking of memory also connects to certain contexts, which involves our living environment, mental and physical state, as well as social atmosphere (Yang 273274). After suffering from the war, the members of the Martin family return to peace in their minds. The chance to reunite and talk provides them with clues to the scenes and sounds of their family life in Galloway in the past, which are combined with their psychological imagination, so that the warm family memories associated with the old house can be backtracked many years later. The old house becomes an asylum for spirits, invoking a desire to return. During this process, the emotional ties between them can be reunited.

The essence of "returning hometown" in novels generally consists of two levels, one is the practical returning home, and the other is the backtracking of memory (He 38). In May 1946, George Martin dies in the underground apartment in New York. The family then sends his body back to his hometown of Lacoshua for burial. The quiet town takes on a familiar soundscape: “...the summer bugs flip-flopped in silent air, a dog barked far away, voices murmured across the hush of the fields from farms and from Lacoshua". "...thronging faintly with the sound of church bells in the distant air of the New Hampshire countryside" (Kerouac 491; 482). At the funeral, the family has a real reunion, and George's distant relatives and friends come from around the town to see him off. "Faint flashes of remembrance and recognition haunted the minds of the young Martins as the relatives trooped about, faces remembered from some childhood comprehension, faces changed and grown older yes still hauntingly familiar, faces that reminded them of the brooding pine forest a night of New Hampshire" (Kerouac 486). The fervent talk of family reunion and the evocative resonance of past memories make the mournful funeral atmosphere lively and warm. Martin family members' memories of the smalltown space, which are accumulated through rich senses in their childhood, are not private and individualized, but are collective memories shared by the whole family. Furthermore, rooted in the land where townspeople live together, these collective memories are also shared and passed on by the whole community in Lacoshua. Returning hometown is a ritual that must be experienced in the process of spiritual growth (He 156); it re-establishes the emotional connection with the individuals and their hometown, and rebuilds the sense of place through the backtracking of memory. After a brief stay in his father's hometown, Peter Martin finally chooses to travel alone. After experiencing the difficulties and confusion in the town and the city, he chooses to explore the meaning of life in the form of "on the road". This time, he leaves home in a state of mind quiet different from the time when he has left Galloway countless times before, because "the spiritual returning" has rebuilt his spiritual homeland, leaving him no longer alone or afraid. As Yi-Fu Tuan indicated, the significance of sense of place lies in that, "as embodied beings we need to feel content in a place of our own, one with a distinctive personality and ambience, its own cultural imprint, its own community of plants and animals, of which we are a part and toward which we therefore owe neighborly consideration and respect. But as mind and spirit, we are often elsewhere-and that too is as it should be" (57-58). The influence of sense of place on people is not limited to the specific space in which the body is located, and the spiritual homeland can often be woken up by the stimulus of the senses, just as the end of the novel is written: " $[\mathrm{w}]$ hen the railroad trains moaned, and river-winds blew, bringing echoes through the vale, it was as if a wild hum of voices, the dear voices of everybody he had known, were crying:' Peter, Peter! Where are you going, Peter"' (Kerouac 499).

"Place" is closely related to human's body and soul. People grow and live in specific places and are nurtured by places. Over a long period of audiovisual experience, people deepen their understanding of the place and blend these sensory experiences with their personal emotional experiences to form a complex connection. The significance of "place" is not only the shelter of the body, but also the emotional ties of family, and the geographical ties of regions. When we give the place enough recognition and love, and form strong feelings of place in our mind, then, even if we live elsewhere, the sound memories of the place hidden in our heart will also make our soul back to the spiritual homeland.

\section{REFERENCES}

[1] Farina, Almo. Soundscape Ecology, Principles, Patterns, Methods and Applications. Heidelberg: Springer Dordrecht, 2014. 
[2] Schafer, R. Murray. Our Sonic Environment and the Soundscape, the Tuning of the World. Rochester: Destiny Books, 1997.

[3] Liu Aili, et al. "Progress in Soundscape Studies from the Perspective of Cultural Geography" (wen hua di li xue shi jiao xia de sheng jing yan jiu ji xiang guan jin zhan). Progress in Geography 11(2014): 14521461 .

[4] Kerouac, Jack. The Town and the City. London: Penguin Books Ltd, 2011.

[5] Kerouac, Jack. The Town and the City (zhen yu cheng). Trans. Mo Qi. Beijing: People's Literature Publishing House, 2013.

[6] He Ping. A Study on the Motif of Returning to hometown in Modern Novels (xian dai xiao shuo huan xiang mu ti yan jiu). Shanghai: Fudan University Press, 2012.

[7] Fu Xiuyan. “On Soundscape” (lun yin jing). Foreign Literature Studies 5(2015): 59-69.

[8] Snyder, Gary. The Practice of The Wild, Berkeley: Counterpoint Press, 2004.

[9] Tuan, Yi-Fu. Space and Place: the Perspective of Experience. Minneapolis: University of Minnesota Press, 2001.

[10] _CCommunity, Society and Individual”. American Geographical Society 3(2002): 307-318.

[11] _ “Sense of Place: What Does it Mean to be Human”. American Journal of Theology\&Philosophy 1(1997): 47-58.

[12] Zhou Zhiqiang. The Ear of Aestheticism - the Voice Politics in "the Voice of China" and "I Am a Singer" (wei mei zhu yi de er duo-zhong guo hao sheng yin wo shi ge shou yu sheng yin de zheng zhi). Literature \& Art Studies 6(2013): 5-14.

[13] Niu Nansen. "Educational Thinking on Family Atomization" (jia ting yuan zi hua de jiao yu xue si kao). Journal of Sichuan Normal University Social Science Edition 4(2012): 117-121.

[14] Sun Xiaotang. "Alienation and Loneliness: the Experience and Imagination of the City of the Post80 s"(shu li yu gu du: 80 hou de cheng shi jing yan yu xiang xiang). Contemporary Writers Review 4(2015): 139-143.

[15] Yang Zhiliang, Sun lianrong, TangJinghua, Eds. Memory Psychology (ji yi xin li xue). Shanghai: East China Normal University Press, 2012.

\section{AUTHOR'S BIOGRAPHY}

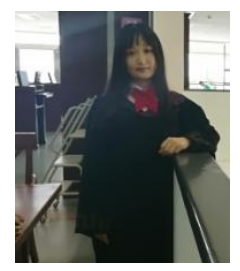

Shuyao Huang, earned a Bachelor of Arts degree in English from Southwest University, is now a graduate student of English Language and Literature in Hunan University, China. Her research interest is American literature, especially the works of the "Beat Generation" writers.

Citation: Shuyao Huang, Joan Qionglin Tan. “The Loss and Backtracking of Sense of Place - Soundscapes in The Town and the City " International Journal on Studies in English Language and Literature (IJSELL), vol 6, no. 6, 2018, pp. 9-14. doi:http://dx.doi.org/10.20431/2347-3134.0606002.

Copyright: (C) 2018 Authors. This is an open-access article distributed under the terms of the Creative Commons Attribution License, which permits unrestricted use, distribution, and reproduction in any medium, provided the original author and source are credited. 